\title{
CHALLENGE BOARD SEBAGAI MEDIA UNTUK MENURUNKAN PERILAKU BUANG AIR BESAR DI CELANA (SOILING) PADA ANAK
}

\author{
Ulin Nuri Mauludiyah', IGAA Noviekayati \\ ${ }^{12}$ Magister Psikologi Profesi, Universitas 17 Agustus 1945 Surabaya. Indonesia \\ Email: ulin.newrie@gmail.com ${ }^{1}, \underline{\text { ekayatinovi@gmail.com }}{ }^{2}$
}

C2018 -JPT Fakultas Psikologi Universitas Negeri Makassar. Ini adalah artikel dengan akses terbuka di bawah licenci CC BY-NC-4.0 (https://creativecommons.org/licenses/by-nc/4.0/ ).

\begin{abstract}
ABSTRAK
Penelitian ini bertujuan untuk menurunkan perilaku buang air besar di celana (soiling) pada anak. Subjek berjenis kelamin laki-laki dan berusia 9 tahun. Peneliti memberikan intervensi menggunakan challenge board sebagai media untuk menurunkan perilaku tersebut. Challenge board merupakan media yang peneliti kembangkan dengan mengikuti kaidah-kaidah teknik response cost. Terapi ini didahului dengan memberikan penjelasan kepada subjek tentang cara buang air besar yang baik dan benar. Kemudian dilanjutkan dengan membuat kesepakatan bahwa perilaku buang air besar di celana (soiling) harus diubah, sebelum subjek masuk pada tahap menyelesaikan tantangan-tantangan yang diberikan. Metode yang digunakan dalam penelitian ini adalah kualitatif dengan pendekatan studi kasus. Hasil penelitian ini menunjukkan bahwa penggunaan media challenge board efektif untuk menurunkan perilaku buang air besar di celana (soiling) pada subjek yang berusia 9 tahun, dan tidak memiliki keterbatasan inteligensi. Perilaku buang air besar di tempatnya, juga akan meningkatkan rasa percaya diri subyek ketika berinteraksi dengan orang lain.
\end{abstract}

Kata kunci: Challenge Board, Perilaku Buang Air Besar di Celana, Soiling.

\begin{abstract}
The study aims to lower bowel behavior in the pants (soiling) of children. The subject is 9 year old boy. Researchers intervene using the challenge board as a medium to lower the behaviour. Challenge board is a medium that is developed by the rules of the response cost technique. This therapy is preceded by providing explanation to the subject about how to defecate well and correctly. Then proceed by making a deal that the behavior of defecation in the pants (soiling) must be changed, before enters in the stage of completing the given challenges. The method used in research is qualitative with a case study approach. The results of this study show that the use of the Challenge Board is effective to lower bowel behavior in the pants (soiling) on the subject.
\end{abstract}

Keywords: Challenge Board, bowel behaviour in pants, Soiling.

\section{PENDAHULUAN}

Masa kanak-kanak merupakan masa yang dipenuhi oleh kegiatan bermain dan belajar. masa kanak-kanak dimulai setelah melewati masa bayi yang penuh ketergantungan. Menurut (Hurlock, 2011), masa kanak-kanak dimulai kira-kira usia 2 tahun sampai anak matang secara seksual, kira-kira usia 13 tahun untuk perempuan dan 14 tahun untuk laki-laki. Masa kanak- 
kanak dibagi menjadi 2 periode, yaitu periode awal (2 - 6 tahun) dan periode akhir (6 tahun - tiba saatnya anak matang secara seksual).

Setiap periode masa kanak-kanak memiliki ciri dan tugas perkembangan masing-masing. Salah satu tugas perkembangan anak yang harus dicapai adalah mampu memperhatikan kebersihan. Untuk mewujudkan tugas perkembangan ini, banyak orangtua yang menerapkan toilet training pada anak-anak mereka. Diungkapkan oleh (Hurlock, 2011), toilet training hendaknya dimulai dari usia 2 tahun. Hal ini untuk memudahkan anak untuk masuk pada tugas perkembangan selanjutnya, yaitu tugas-tugas perkembangan yang berhubungan dengan kehidupan sosial. Permasalahan yang terjadi adalah, tidak semua anak melewati tugas perkembangan dalam memperhatikan kebersihan diri dengan baik. Terkadang dijumpai, anak pada periode akhir belum mampu untuk memperhatikan kebersihan dirinya. Hal ini terlihat dari perilaku mereka ketika buang air besar di celana.

Perilaku buang air besar di celana sering disebut juga dengan istilah soiling. Perilaku ini biasanya muncul pada anak di atas usia 4 tahun. Menurut RN Plas (dalam Rosalina, 2004), soiling merupakan salah satu bentuk konstipasi yang menyebabkan buang air besar sedikit-sedikit di celana. Hal ini senada dengan yang diungkapkan oleh (Matson \& LoVullo, 2009), bahwa soiling merupakan noda kecil di celana dalam yang dikarenakan adanya kotoran dari feces.

Soiling merupakan salah bentuk konstipasi yang sering disamakan dengan perilaku enkopresis. Kedua hal tersebut berbeda, meskipun gejala yang tampak adalah sama, yaitu buang air besar di celana. Perbedaan mendasar antar kedua perilaku tersebut adalah pada konsistensi dan jumlah feces. Konsistensi soiling lebih keras dibandingkan enkopresis dan jumlah feces di celana hanya sedikit jika dibandingkan dengan enkropesis. Soiling seringkali disadari, sedangkan enkopresis tidak (Joinson et al., 2019). Dijelaskan lebih lanjut oleh Joinson et al., (2019), berdasarkan hasil penelitiannya diungkapkan bahwa 20\% anak pernah mengalami soiling tanpa diikuti adanya konstipasi. Perilaku soiling dapat disebabkan karena beberapa hal, diantaranya adalah: faktor genetik, biologis dan neurologis, diet yang buruk, toilet training yang tidak efektif, serta faktor psikososial, seperti sembelit karena adanya masalah psikologis dan stres pada anak. Dikutip dari hasil penelitian (Heron, Grzeda, Tappin, Von Gontard, \& Joinson, 2018), ada beberapa hal yang turut andil dalam menyebabkan perilaku soiling pada anak, diantaranya: satus sosial ekonomi keluarga selama periode antenatal, tingkat 
pendidikan ibu, lamanya kehamilan dan kelahiran, pelatihan toilet training yang buruk.

Perilaku soiling pada menjadi perhatian penting bagi para orangtua. Langkah-langkah yang tepat dan efektif, perlu dilakukan untuk mengatasi perilaku soiling pada anak ini. Salah satu langkah yang bisa dilakukan adalah dengan menggunakan media challenge board. Media challenge board ini merupakan media yang peneliti kembangkan berdasarkan teknik modifikasi perilaku response cost. Penggunaan nama challenge board didasarkan pada salah satu hobi subjek, yaitu menonton acara challenge di channel Youtube. Penggunaan media challenge board ini untuk membuat subjek termotivasi dalam melakukan serangkaian proses terapi yang akan ia jalani. Challenge board berisi poin awal yang dimiliki oleh subjek dan jumlah target poin yang harus dikumpulkan.

Challenge board mengacu pada kaidah-kaidah modifikasi perilaku dengan menggunakan teknik response cost, yaitu sebuah metode operant conditioning yang didasarkan pada prinsip-prinsip hukuman dan melibatkan penghilangan suatu stimulus positif untuk mengurangi perilaku tertentu (Henington \& Dogget, dalam Erford, 2017). Response cost sering disebut juga dengan cost contingency, yang seringkali berbentuk sistem poin atau token. Individu akan mendapatkan poin ketika memperlihatkan perilaku yang diinginkan dan akan kehilangan poin ketika memperlihatkan perilaku negatif (Erford, 2017). Dijelaskan lebih lanjut oleh (Erford, 2017), bahwa response cost merupakan lawan dari reiforcement positif. Reward akan diberikan ketika pada akhir periode individu masih memiliki sejumlah token yang sudah disepakati sebelumnya.

Sebelum menerapkan teknik ini, penting untuk menyelesaikan tiga langkah penting di bawah ini, yaitu :

a. Identifikasi perilaku spesifik yang akan ditargetkan, cobalah untuk fokus pada satu atau dua perilaku saja.

b. Putuskan hukuman atau hadiah untuk setipa munculnya perilaku yang diinginkan.

c. Memberikan penjelasan kepada klien tentang aturan main dari response cost.

Teknik response cost dapat divariasikan dengan berbagai macam model dan media yang digunakan. Hal terpenting yang harus diperhatikan adalah stimulus positif yang telah ditetapkan dalam pembentukan perilaku baru (Erford, 2017). Teknik ini telah sukses digunakan berpuluh-puluh tahun untuk mengangani kasus individu, kelompok, maupun komunitas. Diungkapkan oleh Salend dan Allen (dalam Erford, 2017), response cost yang dikelola secara eksternal dan internal sama-sama efektif dalam mengurangi 
perilaku buruk siswa-siswa disabilitas belajar di kelas.

\section{METODE}

Penelitian ini menggunakan metode penelitian kualitatif, dengan jenis pendekatan studi kasus. Peneliti memperoleh data melalui proses asesment psikologi, yang terdiri atas observasi, dan wawancara.

Subjek pada penelitian ini berinisial $\mathrm{K}$, berjenis kelamin laki-laki, dan berusia 9 tahun. Berdasarkan hasil asesmen yang dilakukan oleh peneliti, subjek didiagnosa mengalami gangguan perilaku buang air besar di celana (soiling).

Subjek dilahirkan secara normal dan tumbuh berkembang seperti anak seusianya. Pada usia 1 tahun, subjek sudah mulai bisa berbicara meskipun ada pengucapan huruf yang belum optimal. Subjek bersekolah PAUD saat berusia 3 tahun 6 bulan, dan mulai diajarkan toilet training oleh ibunya. Toilet training yang diajarkan tersebut berhasil dilakukan oleh subjek. Namun, pelaksanaan toilet training ini menjadi terhambat saat subjek kembali dari berlibur bersama orangtuanya. Ketika berlibur, orangtua subjek memakaikan popok saat berada di pesawat dan mengunjungi objek wisata. Beberapa hari setelah pulang berlibur, subjek kembali meminta memakai popok kepada ibunya. Sehingga, subjek selalu memakai popok ke sekolah meskipun ia sudah kelas 1 SD. Hal ini berlangsung selama 3 bulan, sebelum orangtua subjek benar-benar tidak memperbolehkannya memakai popok kembali. Setelah pemakaian popok dihentikan, subjek mulai melakukan buang air besar di celana. Frekuensi buang air besar di celana tersebut terjadi setiap hari, dan lebih dari 1 kali dalam sehari. Hal ini diketahui oleh ibu subjek, karena selalu mendapati ada kotoran/feces di celana dalam subjek. Feces yang dikeluarkan oleh subjek sedikit-sedikit, menyerupai orang yang sedang mengalami konstipasi. Perilaku tersebut berlangsung sejak subjek duduk di bangku kelas 1 SD hingga saat ini.

Subjek merupakan anak yang introvert, ia cenderung kurang mampu berinteraksi dan beradaptasi di lingkungan baru. Namun, subjek memiliki keinginan untuk bisa mandiri dan dapat berteman dengan siapapun. Hal ini mendorong subjek untuk bisa beradaptasi dengan lingkungannya, meskipun harus dibantu terlebih dahulu oleh orangtuanya yang merupakan sosok utama dalam kehidupan subjek. Lingkungan sosial subjek yang ramai, turut membantunya dalam proses beradapatasi dengan lingkungan sekitar. Subjek mendapatkan kasih sayang yang berlimpah dari orangtua dan keluarga terdekatnya. Namun, hal ini tidak lantas membuat orangtua dan keluarganya memanjakannya. Orangtua dan neneknya 
akan marah ketika subjek mengabaikan nasihat-nasihat yang mereka berikan tentang perilaku buang air besar di celana. Ketika orangtua atau neneknya marah, subjek beranggapan bahwa mereka tidak menyayanginya. Selama ini, subjek tidak pernah mau untuk mengungkapkan alasan perilaku buang air besar di celana yang ia lakukan. Orangtua subjek beranggapan bahwa, ia lebih nyaman menggunakan popok bayi setelah hal itu diterapkan kembali saat liburan. Namun, penyebab subjek buang air besar di celana yang sebenarnya adalah karena ia takut air akan masuk ke lubang-lubang di dalam tubuhnya. Hal ini juga diperkuat dengan sikap subjek yang tidak suka jika disuruh mandi. Ia akan menghindari bagian-bagian di tubuhnya yang memiliki lubang untuk dialiri air. Ketakutan ini bermula saat ada air yang memasuki telinganya, ketika ia sedang mandi saat liburan. Hal itu membuat subjek takut ada air akan masuk kembali ke telinganya dan semua lubanglubang yang ada di tubuhnya.

Berdasarkan hasil pengukuran yang diperoleh, peneliti menggunakan challenge board sebagai media dari penerapan teknik response cost, untuk menurunkan perilaku buang air besar di celana (soiling). Pemberian terapi ini dilakukan di rumah subjek, dan diharapkan mampu untuk membantu subjek dalam melakukan perilaku buang air besar secara baik dan benar. Terapi ini diberikan dalam 7 sesi. Tahapan terapi ini, mengacu kepada pola tahapan response cost yang dikemukakan oleh Erford (2017), yaitu :

a. Menentukan target perilaku yang akan diubah. Pada tahapan ini, target perilaku yang akan diubah ditentukan secara bersama oleh klien, orangtua, dan peneliti.

b. Menentukan hukuman dan reward yang akan diterima oleh subjek. Hal-hal yang harus dipertimbangkan dalam tahap ini antara lain keinginan subjek dalam waktu dekat, bentuk stiker poin yang disukai oleh subjek.

c. Memberitahukan tentang aturan main dalam pelaksanaan terapi. Tahapan ini bertujuan untuk menyamakan persepsi antara peneliti dengan orangtua subjek. Selain itu, tahapan ini dilakukan agar psores terapi berjalan sesuai dengan kaidah pelaksanaan terapi yang benar. Sehingga, keberhasilan dalam proses terapi akan lebih besar dan efektif.

Rancangan pelaksanaan challenge board sebagai media teknik response cost untuk menurunkan perilaku buang air besar di celana pada subjek, dapat dilihat pada tabel 1 di bawah ini : 
Tabel 1. Rancangan pelaksanaan challenge board

\begin{tabular}{|c|c|}
\hline Sesi & Kegiatan \\
\hline 1 & $\begin{array}{l}\text { - Menjelaskan kepada subjek bahwa buang air besar yang baik untuk anak } 9 \text { tahun adalah di kamar } \\
\text { mandi. Menjelaskan dengan contoh kesulitan-kesulitan yang akan subjek alami jika perilaku } \\
\text { tersebut tidak diubah. Media video dari Youtube juga dilibatkan untuk memberikan gambaran } \\
\text { kepada subjek tentang perilaku buang air besar yang baik di kamar mandi, akibat anak yang } \\
\text { tidak buang air besar di kamar mandi, dan cara buang air besar serta membersihkan yang benar. } \\
\text { - Setelah subjek memahami, praktikan dan subjek membuat kesepakatan bahwa perilaku buang air } \\
\text { besar di celana (soiling) harus diubah. }\end{array}$ \\
\hline 2 & $\begin{array}{l}\text { - Mencari tahu hal yang paling disukai oleh subjek. } \\
\text { - Mencari tahu keinginan subjek dalam waktu dekat. Hal ini untuk diberikan sebagai reward } \\
\text { ketika subjek berhasil mengumpulkan stiker sebanyak jumlah yang telah disepakati. } \\
\text { - Mendiskusikan bentuk stiker yang disukai oleh subjek. }\end{array}$ \\
\hline 3 & $\begin{array}{l}\text { - Menjelaskan aturan main response cost kepada subjek, ibu, dan nenek, yaitu : } \\
\text { Di awal, subjek akan mendapatkan poin awal dengan jumlah yang berbeda. } \\
\text { - Ketika subjek dapat melaksanakan tugasnya di hari } \\
\text { tersebut, ia akan mendapat tambahan } 1 \text { stiker. } \\
\text { - Ketika subjek tidak dapat melaksanakan tugasnya di } \\
\text { hari tersebut, subjek akan kehilangan } 1 \text { stiker. } \\
\text { Berdiskusi antara peneliti, ibu, dan nenek subjek tentang jumlah stiker poin awal dan stiker yang } \\
\text { harus dikumpulkan oleh subjek selama waktu yang ditentukan. }\end{array}$ \\
\hline 4 & $\begin{array}{l}\text { - Menyerahkan challenge board beserta stiker kepada ibu. Stiker tidak disimpan oleh subjek, } \\
\text { melainkan disimpan oleh ibu. } \\
\text { - Memberikan instruksi kepada ibu, ketika subjek berhasil melakukan tugasnya, ibu akan } \\
\text { memberikan } 1 \text { stiker untuk subjek tempel di challenge board, sesuai dengan hari saat itu. Ketika } \\
\text { subjek tidak melaksanakan tugasnya, ibu subjek akan memasukkan } 1 \text { buah stiker dari poin awal } \\
\text { ke dalam sebuah kotak tertutup. } \\
\text { Meminta ibu dan nenek mengingatkan subjek setiap pagi, setelah pulang sekolah, saat petang, } \\
\text { dan sebelum tidur untuk buang air besar di kamar mandi. Selain itu juga mengingatkan tentang } \\
\text { challenge yang sedang subjek lakukan. Pemberian dukungan dan motivasi juga penting } \\
\text { dilakukan. }\end{array}$ \\
\hline 5 & $\begin{array}{l}\text { - Melakukan kunjungan ke rumah subjek untuk memeriksa challenge board pada tahap } \\
\text { pelaksanaan di } 3 \text { hari pertama, serta bertanya tentang perasaan subjek dalam melakukan tugas } \\
\text { tersebut. }\end{array}$ \\
\hline 6 & $\begin{array}{l}\text { - Kunjungan ke rumah subjek untuk memeriksa challenge board pada tahap pelaksanaan di } 5 \text { hari } \\
\text { selanjutnya, serta bertanya tentang perasaan subjek dalam melakukan tugas tersebut. }\end{array}$ \\
\hline 7 & $\begin{array}{l}\text { - Kunjungan ke rumah subjek untuk memeriksa challenge board pada tahap pelaksanaan di } 6 \text { hari } \\
\text { selanjutnya, serta bertanya tentang perasaan subjek dalam melakukan tugas tersebut. }\end{array}$ \\
\hline
\end{tabular}

Alat yang digunakan dalam melakukan pengambilan data dan intervensi adalah sebagai berikut : buku catatan, alat-alat tes psikologi, Challenge board, stiker poin awal, stiker poin tugas, video cara buang air besar yang baik dan benar. Stiker poin awal diberikan oleh peneliti di awal masing-masing fase challenge/tantangan. Sedangkan, stiker poin tugas diberikan ketika subyek berhasil melakukan challenge/tantangan. Video cara buang air besar yang baik dan benar diberikan sebelum subyek menjalankan challenge/tantangan.

\section{HASIL}

Adapun hasil dari pelaksanaan challenge board ini dapat dilihat pada tabel 
berikut:

Tabel 2. hasil pelaksanaan challenge board

\begin{tabular}{|c|c|c|}
\hline Sesi & Kegiatan & Hasil \\
\hline 1 & $\begin{array}{l}\text { Memberikan penjelasan kepada subjek tentang } \\
\text { buang air besar yang baik dan benar, serta } \\
\text { membuat kesepakatan dengan subjek bahwa } \\
\text { perilaku buang air besar di celana harus diubah. }\end{array}$ & $\begin{array}{l}\text { Subjek paham tentang perilaku buang air besar } \\
\text { yang benar. Subjek juga sepakat bahwa perilaku } \\
\text { buang air besar di celana harus diubah. }\end{array}$ \\
\hline 2 & $\begin{array}{l}\text { - Mencari tahu hal yang paling disukai oleh } \\
\text { subjek, untuk menentukan media yang paling } \\
\text { tepat. } \\
\text { - Mencari tahu keinginan subjek dalam waktu } \\
\text { dekat. Hal ini untuk diberikan sebagai reward } \\
\text { ketika subjek berhasil mengumpulkan stiker } \\
\text { sebanyak jumlah yang telah disepakati. } \\
\text { - Mendiskusikan bentuk stiker yang disukai oleh } \\
\text { subjek. }\end{array}$ & $\begin{array}{l}\text { - Peneliti dan subjek memberikan nama untuk } \\
\text { media yang akan dipakai, yaitu challenge } \\
\text { board. Hal ini dibuat berdasarkan kegemaran } \\
\text { subjek menonton acara challenge di Youtube. } \\
\text { - Keinginan subjek antara lain susu kotak rasa } \\
\text { coklat, makan di McD, serta main bola dengan } \\
\text { ayah. } \\
\text { - Subjek memilih stiker bentuk smile berwarna } \\
\text { kuning. }\end{array}$ \\
\hline 3 & $\begin{array}{l}\text { - Menjelaskan aturan main response cost kepada } \\
\text { subjek, ibu, dan nenek, yaitu: } \\
\text { O Di awal, subjek akan mendapatkan poin } \\
\text { awal dengan jumlah yang berbeda. } \\
\text { Ketika subjek dapat melaksanakan } \\
\text { tugasnya di hari tersebut, ia akan } \\
\text { mendapat tambahan } 1 \text { stiker. } \\
\text { O Ketika subjek tidak dapat melaksanakan } \\
\text { tugasnya di hari tersebut, subjek akan } \\
\text { kehilangan } 1 \text { stiker. } \\
\text { Berdiskusi antara peneliti, ibu, dan nenek } \\
\text { subjek tentang jumlah stiker yang harus } \\
\text { dikumpulkan oleh subjek selama waktu yang } \\
\text { ditentukan. }\end{array}$ & $\begin{array}{l}3 \text { hari pertama sebanyak } 4 \text { stiker } \\
\text { - } 5 \text { hari selanjutnya sebanyak } 5 \text { stiker } \\
\text { - } 6 \text { hari selanjutnya sebanyak } 6 \text { stiker } \\
\text { Sedangkan untuk poin awal, yaitu : } \\
\text { - } 3 \text { hari pertama sebanyak } 5 \text { stiker (target } 1 \text { kali } \\
\text { perilaku yang diinginkan muncul) } \\
\text { - } 5 \text { hari selanjutnya sebanyak } 6 \text { stiker (target } 2 \\
\text { kali } \\
\text { perilaku yang diinginkan muncul) } \\
\text { - } 6 \text { hari selanjutnya sebanyak } 7 \text { stiker (target } 3 \\
\text { kali } \\
\text { perilaku yang diinginkan muncul) }\end{array}$ \\
\hline 4 & $\begin{array}{l}\text { - Menyerahkan challenge board beserta stiker } \\
\text { kepada ibu. Stiker tidak disimpan oleh subjek, } \\
\text { melainkan disimpan oleh ibu. } \\
\text { Memberikan instruksi kepada ibu, ketika } \\
\text { subjek berhasil melakukan tugasnya, ibu akan } \\
\text { memberikan } 1 \text { stiker untuk subjek tempel di } \\
\text { challenge board, sesuai dengan hari saat itu. } \\
\text { Ketika subjek tidak melaksanakan tugasnya, } \\
\text { ibu subjek akan memasukkan } 1 \text { buah stiker dari } \\
\text { poin awal ke dalam sebuah kotak tertutup. } \\
\text { Meminta ibu dan nenek mengingatkan subjek } \\
\text { setiap pagi, setelah pulang sekolah, saat } \\
\text { petang, dan sebelum tidur untuk buang air } \\
\text { besar di kamar mandi. Selain itu juga } \\
\text { mengingatkan tentang challenge yang sedang } \\
\text { subjek lakukan. Pemberian dukungan dan } \\
\text { motivasi juga penting dilakukan. }\end{array}$ & $\begin{array}{l}\text { - Ibu dan nenek melaukan tugasnya dengan } \\
\text { optimal }\end{array}$ \\
\hline 5 & $\begin{array}{l}\text { - Kunjungan ke rumah subjek untuk memeriksa } \\
\text { challenge board ( } 3 \text { hari pertama), serta } \\
\text { bertanya tentang perasaan subjek dalam } \\
\text { melakukan tugas tersebut. }\end{array}$ & $\begin{array}{l}\text { - Pada sesi ini, subjek berhasil melakukan tugas } \\
\text { sebanyak } 1 \text { kali, memperoleh jumlah stiker } \\
\text { sebanyak } 4 \text { stiker. Sehingga, subjek berhasil } \\
\text { mendapatkan reward untuk } 3 \text { hari pertama. } \\
\text { - Subjek mengungkapkan bahwa ia merasa keren } \\
\text { karena bisa melakukan tuganya dan mendapat } \\
\text { hadiah. }\end{array}$ \\
\hline 6 & $\begin{array}{l}\text { - Kunjungan ke rumah subjek untuk memeriksa } \\
\text { challenge board (5 hari selanjutnya), serta }\end{array}$ & $\begin{array}{l}\text { - Pada sesi ini, subjek berhasil melakukan tugas } \\
\text { sebanyak } 1 \text { kali, memperoleh jumlah stiker }\end{array}$ \\
\hline
\end{tabular}




\begin{tabular}{|c|c|c|}
\hline & $\begin{array}{l}\text { bertanya tentang perasaan subjek dalam } \\
\text { melakukan tugas tersebut. }\end{array}$ & $\begin{array}{l}\text { sebanyak } 3 \text { stiker. Sehingga, subjek belum } \\
\text { berhasil mendapatkan reward untuk } 5 \text { hari } \\
\text { selanjutnya. } \\
\text { - Subjek merasa sedih karena tidak berhasil. } \\
\text { Praktikan memberikan dukungan untuk subjek } \\
\text { agar kembali berusaha, begitu juga dengan ibu } \\
\text { dan nenek subjek. Beberapa lama kemudian, } \\
\text { subjek berhenti menangis dan berjanji akan } \\
\text { berusaha lagi. }\end{array}$ \\
\hline 7 & $\begin{array}{l}\text { - Kunjungan ke rumah subjek untuk memeriksa } \\
\text { challenge board (6 hari selanjutnya), serta } \\
\text { bertanya tentang perasaan subjek dalam } \\
\text { melakukan tugas tersebut. }\end{array}$ & $\begin{array}{l}\text { - Pada sesi ini, subjek berhasil melakukan tugas } \\
\text { sebanyak } 4 \text { kali, memperoleh jumlah stiker total } \\
\text { sebanyak } 9 \text { stiker. Subjek melampaui target } \\
\text { awal yang ditentukan oleh praktikan bersama } \\
\text { ibu dan nenek. Subjek berhasil mendapatkan } \\
\text { reinforcement untuk } 6 \text { hari selanjutnya. } \\
\text { - Subjek merasa lebih keren karena jumlah } \\
\text { stikernya lebih banyak dari target yang ada di } \\
\text { challenge board. Selain itu, subjek mengaku } \\
\text { sudah tidak sabar menunggu ayahnya datang } \\
\text { dan bermain bola bersamanya. }\end{array}$ \\
\hline
\end{tabular}

\section{PEMBAHASAN}

Berdasarkan tabel 2 di atas, subjek melakukan setiap tahapan dalam proses terapi dengan sangat baik. Subjek bersemangat untuk menyelesaikan challenge yang diberikan kepadanya. Meskipun demikian, ada saatnya subjek mengalami hambatan ketika melakukan proses terapi, seperti masih adanya feces di celana dalam $\mathrm{K}$ meskipun frekuensi dalam sehari tidak sebanyak sebelumnya.

Dukungan dari orangtua dan nenek subjek, membuatnya lebih bersemangat dalam menyelesaikan tantangan yang diberikan. Subjek mengungkapkan bahwa subjek senang, karena ibu dan neneknya sudah tidak marah-marah lagi ketika menyuruh subjek buang air besar di kamar mandi. Setelah proses intervensi selesai, subjek tidak perlu diingatkan untuk buang air besar di kamar mandi. Bahkan, subjek meminta maaf kepada ibu dan neneknya, jika subjek tanpa sadar buang air besar di celana. Subjek akan cepat-cepat ke kamar mandi untuk mengganti celana dan membersihkan diri tanpa perlu disuruh.

Selain melakukan terapi kepada subjek, peneliti juga melakukan psikoedukasi kepada ibu dan nenek subjek. Hal ini dilakukan dengan cara sebagai berikut :

- Memberikan penjelasan kepada ibu dan nenek tentang kondisi subjek secara lebih mendetail.

- Menjelaskan kebutuhan subjek, seperti dukungan, motivasi, serta tidak marahmarah ketika menginginkan perubahan perilaku dari subjek.

- Menjaga komunikasi dengan subjek agar tetap baik, tanpa ada nada marah dan menakut-nakuti. 
- Mempertahankan perubahan perilaku yang sudah dicapai oleh subjek. Salah satu hal ini bisa dilakukan adalah selalu mengajak subjek bercerita tentang pengalamannya melakukan challenge tersebut, dan terus memotivasi untuk bisa mendapatkan hasil lebih baik lagi.

Psikoedukasi diharapkan mampu untuk meningkatkan motivasi orangtua dalam mempertahankan dan meningkatkan perubahan perilaku yang sudah diperoleh oleh subjek. Motivasi orangtua, tertama ibu dapat mempengaruhi keberhasilan dari pelaksanaan ini. Dijelaskan dalam hasil penelitian yang dilakukan oleh Munjidah dan Retnosari (2019), bahwa ibu yang memiliki motivasi tinggi dapat meningkatkan keberhasilan dalam membuat anak melakukan perilaku buang air besar di kamar mandi.

Pada penelitian ini, challenge board yang dipakai sebagai media dalam pemberian teknik terapi response cost efektif untuk menurunkan perilaku buang air besar di celana pada subjek. Hal ini bisa di ketahui dari hasil sebelum dan sesudah pemberian terapi. Sebelum diberikan terapi, subjek melakukan perilaku buang air besar di celana setiap hari, dengan frekuensi 1-3 kali sehari. Meskipun ada keinginan dari subjek untuk bisa buang air besar di kamar mandi, namun subjek merasa khawatir untuk melakukan hal tersebut. Kurangnya pengetahuan dari orangtua juga menghambat keinginan subjek untuk bisa buang air besar di kamar mandi terwujud.

Setelah pemberian terapi, subjek mengungkapkan bahwa ia senang, karena ibu dan neneknya sudah tidak marahmarah lagi ketika menyuruhnya buang air besar di kamar mandi. Selain itu, subjek sudah tidak perlu diingatkan untuk buang air besar di kamar mandi. Bahkan subjek meminta maaf kepada ibu dan neneknya, jika ia tanpa sadar buang air besar di celana. Ia akan cepat-cepat ke kamar mandi untuk mengganti celana dan membersihkan diri tanpa perlu disuruh. Subjek juga mengungkapkan bahwa ia bahagia bisa melakukan tantangantantangan tersebut. Ibu subjek juga mengungkapkan bahwa, subjek sudah mulai terbiasa dengan kegiatan buang air besar di kamar mandi. Selain itu, ibu juga mengungkapkan bahwa ketika meminta subjek untuk memperbaiki perilakunya, akan lebih mudah jika ibu mengatakan punya challenge untuk subjek. Ia cenderung akan berusaha untuk melakukannya dan tidak lagi mengabaikan.

Keberhasilan penggunaan media challenge board ini, tak bisa terlepas dari peran serta dan dukungan dari orangtua dan keluarga terdekat subjek. Menurut hasil penelitian dari (Kurniasih, 2019), sebanyak $76,2 \%$ responden penelitian, yaitu orangtua memiliki dukungan positif terhadap keberhasilan pelaksanaan toilet 
training anak. Dukungan keluarga, terutama ibu sebagai sosok yang selalu menemani anak merupakan dukungan bermakna bagi anak. Ibu yang selalu memberikan waktunya untuk anak, akan memberikan efek yang lebih optimal dalam melakukan toilet training daripada ibu yang terlalu sibuk dengan aktivitasnya (Yasin \& Aulia, 2019). Salah satu penyebab munculnya dukungan positif ini adalah karena adanya pengetahuan dari pihak keluarga tentang pelaksanaan toilet training. Penggunaan teknik response cost dalam pemberian terapi challenge board ini, memungkinakn orangtua dan anggota keluarga terdekat memperoleh informasi dan wawasan lebih tentang cara-cara untuk menurunkan perilaku soiling pada subjek.

Peran orangtua dalam pelaksanaan challenge board ini merupakan seperangkat tindakan dan tingkah laku orangtua dalam membantu dan membimbing anak dalam melalukan aktivitasnya, sehingga anak memiliki semangat yang tinggi dalam menyelesaikan aktivitasnya tersebut dan belajar untuk menjadi lebih lagi (Mendur, Rottie, \& Bataha, 2018). Peran orangtua tidak dapat dilepaskan dari pola asuh orangtua dalam keluarga. Pola asuh yang diterapkan orangtua dapat meningkatkan perilaku self care yang dimiliki oleh anak (Lestari, 2018).

Motivasi juga sangat diperlukan dalam keberhasilan pelaksanaan terapi challenge board ini. Motivasi dapat menjadi pendorong atau penggerak bagi individu dalam melakukan sesuatu (Munjidah \& Retnosari, 2019). Motivasi dalam pelaksanaan terapi challenge board ini, diperoleh dari dukungan orangtua dan reward yang akan memacu meningkatnya motivasi pada subjek.

Untuk mempertahankan dan meningkatkan perilaku buang air besar di kamar mandi, ada beberapa saran yang diberikan peneliti kepada subjek, orangtua, dan nenek. Saran kepada subjek yaitu hendaknya mempertahankan perubahan positif yang sudah ia capai. Ketika ia mengalami kesulitan dalam mempertahankannya, hendaknya dikomunikasikan dengan orangtua atau neneknya. Hal ini dilakukan agar orangtua dan nenek dapat mengetahui kesulitankesulitan yang ia hadapi.

Saran kepada orangtua, hendaknya selalu mencari cara kreatif yang sesuai dengan kesukaan subjek. Hal ini bisa dilakukan dengan cara menemani subjek bermain dan mengajaknya berdiskusi tentang apapun, sehingga subjek akan lebih sering untuk mengungkapkan segala hal tentang dirinya. Ciptakan kondisi rumah yang hangat dan menyenangkan, agar subjek bebas untuk mengemukakan semua perasaannya. Sedangkan untuk nenek subjek, hendaknya mengurangi sikap marah ketika menginginkan perubahan 
perilaku positif dari subjek. Ungkapkanlah sesuatu dengan cara yang lebih bisa diterima anak seusia $\mathrm{K}$, misalnya mengajak subjek untuk memberikan pendapat dari

\section{DAFTAR PUSTAKA}

Erford, B. T. (2017). 40 Teknik yang Harus Diketahui Setiap Konselor (Kedua). Yogyakarta: Pustaka Pelajar.

Heron, J., Grzeda, M., Tappin, D., Von Gontard, A., \& Joinson, C. (2018). Early childhood risk factors for constipation and soiling at school age: An observational cohort study. $B M J$ Paediatrics Open, 2(1), 1-8. https://doi.org/10.1136/bmjpo-2017000230

Hurlock, E. B. (2011). Psikologi Perkembanga, Suatu Pendekatan Sepanjang Sejarah Kehidupan (5th ed.). Jakarta: Penerbit Erlangga.

Joinson, C., Grzeda, M. T., von Gontard, A., \& Heron, J. (2019). Psychosocial risks for constipation and soiling in primary school children. European Child and Adolescent Psychiatry, 28(2), 203-210. https://doi.org/10.1007/s00787-018$1162-8$

Kurniasih, E. (2019). DUKUNGAN KELUARGA PADA ANAK dalam MELAKUKAN TOILET TRAINING di Erwin Kurniasih Akademi Keperawatan Pemkab Ngawi Email: nerserwin.08@gmail.com.1-5.

Lestari, F. P. (2018). Kontribusi Pola Asuh sebuah cerita yang nenek ceritakan. Isi cerita adalah bentuk keinginan nenek terhadap harapan perilaku subjek.

Orangtua terhadap Self Care Skill Anak Tunagrahita di SDLB/C Alpa Kumara Wardhana II Surabaya.

Matson, J. L., \& LoVullo, S. V. (2009). Encopresis, soiling and constipation in children and adults with developmental disability. Research in Developmental Disabilities, 30(4), 799-807. https://doi.org/10.1016/j.ridd.2008.12.00 1

Mendur, J. P., Rottie, J., \& Bataha, Y. (2018). Hubungan Peran Orang tua dengan Kemampuan Toilet Training pada Anak Pra Sekolh di TK GMIM Sion Sentrum Sendangan Kawangkoan Satu. Keperawatan, 6(1), 1-8.

Munjidah, A., \& Retnosari, E. Y. (2019). Motivasi Ibu Mempengaruhi Keberhasilan Pelatihan Buang Air pada Anak Batita. Jurnal Ners Dan Kebidanan (Journal of Ners and Midwifery), 6(2), 156-162.

https://doi.org/10.26699/jnk.v6i2.art.p156 $-162$

Yasin, Z., \& Aulia, N. A. (2019). Dukungan Keluarga Tentang Toilet Training dengan Keberhasilan Toileting pada Anak Usia 1-6 Tahun di PAUD AL Hilal Kabupaten Sumenep. Ilmu Kesehatan, 4(1), 11-20.

https://www.statistikian.com/2012/10/penelitia n-kualitatif.html, diakses 5 November 2019 